\title{
Miseria e nobiltà. Percepciones y decepciones de un bailarín italiano en la Nueva España
}

\author{
Miseria e Nobiltà. Perceptions and Deceptions of an Italian Dancer \\ in New Spain \\ Caterina Camastra* \\ UNIVERSIDAD NACIONAL AUTÓNOMA DE MÉXICO-UNIDAD DE INVESTIGACIÓN SOBRE \\ REPRESENTACIONES CULTURALES Y SOCIALES, saeeda.bai@gmail.com
}

El presente trabajo reconstruye la trayectoria del bailarín italiano Girolamo Marani y su compañía-familia, quienes, entre las últimas décadas del siglo xviı y los principios del XIX, recorrieron los teatros de varios países de Europa, para llegar finalmente a establecerse en la Nueva España. La historia de sus andanzas y de los altibajos de su fama y fortuna es significativa en términos de las prácticas teatrales de la época y sus valores sociales y simbólicos.

Palabras Clave: teatro, baile, siglo XviII, Marani.

This articles reconstructs the trajectory of the Italian dancer Girolamo Marani and his troupe-family who, from the late $18^{\text {th }}$ to early $19^{\text {th }}$ centuries, toured theaters in several European countries, before finally settling in New Spain. The story of their activities and the ups-and-downs of their fame and fortune becomes significant in terms of what it teaches us about theatrical practices in that period and their social and symbolic values.

KEYWORDS: theater, dance, $18^{\text {th }}$ century, Marani.

Fecha de recepción del artículo: 17 de mayo de 2015 / Fecha de aprobación: 20 de octubre de 2015 / Fecha de recepción de la versión final: 23 de octubre de 2015

Torno nella miseria, però non mi lamento: mi basta di sapere che il pubblico è contento.

Antonio de Curtis "Totò"

n la historia de las artes escénicas en el mundo occidental, el
siglo XviII ve nacer una figura que hoy en día consideramos
como normal: el divo de la farándula, el artista orgulloso de

*Este artículo es el primer resultado del proyecto de investigación titulado Itinerancia y transculturación de las compañias teatrales en Hispanoamérica (siglo XVIII y sus alrededores). Repertorios, prácticas escénicas e historias de vida: el caso de la familia Marani, desarrollado en el marco de una estancia posdoctoral realizada en El Colegio de Michoacán. El artículo constituye el adelanto de un libro en proceso de redacción. 
su aplaudido quehacer, de su renombre, de su fama. Muestras de esa actitud, por citar dos ejemplos al azar en esas épocas de las tablas en el orbe hispano, son Francisca "Paca" Ladvenant, tonadillera española, y Margarita Olivares, bailarina del Coliseo de México. La primera, en el último día de las Carnestolendas de 1770, en Zaragoza, "consiguió nada menos que el coche del Regente para volver al teatro, donde el público la reclamaba con sus aplausos"; ${ }^{1}$ la segunda, en 1817 , se presentaba "con extraordinaria inmodestia en sus trages y acciones" y, siendo "reconvenida [...] por el señor corregidor en turno, don Diego Peredo, [...] no solo no se enmendó, sino que se portó con altanería". ${ }^{2}$

Es en la dimensión de la ejecución, la performance, que géneros, modas, obras exitosas y autores reconocidos cobraron vida en las tablas. Llegamos a tener más noticias de las figuras que, en razón de su talento, suerte o novelesca biografía, lograron destacar y sobresalir; más raramente logramos enterarnos de los artistas "de a pie", los "obreros" del escenario, los que, sin embargo, sin alcanzar la condición de ilustres, construyeron en su quehacer cotidiano esos géneros, esas modas y las puestas en escena de esas obras. En este marco, la historia personal de las andanzas del bailarín italiano Girolamo Marani y su compañía familiar, sin ser totalmente desconocida, no ha llamado hasta ahora tanta atención como para merecer un estudio especialmente a ella dedicado. ${ }^{3}$ Sin embargo, su trayectoria vivencial y profesional participa plenamente justo de los movimientos, las influencias, las prácticas que han marcado la historia compartida de la danza y el teatro en Europa y América, entre la segunda mitad

${ }^{1}$ Ricardo del Arco. Zaragoza histórica: evocaciones y noticias (Madrid: Tipografía de la viuda de Justo Martínez, 1928), 166. Véase también Guillermo Fatás Cabeza, De Zaragoza (Zaragoza: Institución Fernando el Católico, 1990), 202. La Real Audiencia de Aragón castigó este "exceso" de la cantarina con cuatro días de cárcel, castigo que no llegó a aplicarse por encontrarse la misma, convenientemente, en Madrid cuando fueron a apresarla (Archivo Histórico Provincial, Zaragoza, AHPZ, J 002086/ 000003).

${ }^{2}$ Archivo General de la Nación, México, AGN, Inquisición, caja 194, sin expediente, fol. 13r.

${ }^{3}$ Los investigadores que más atención han dedicado a los Marani han sido Alberto Dallal y Maya Ramos Smith. Los mencionan también Manuel Mañón, Armando de María y Campos, Enrique de Olavarría y Ferrari, José Sasportes y Germán Viveros. Para las referencias de las obras véase la bibliografía. 
del siglo XVIII y las primeras décadas del XIX. Además, a través de la cotidianidad de un grupo de personas, nos permite una mirada -a ras de suelo y en medio de los acontecimientos en devenir-a las dinámicas sociales y culturales, percepciones y mentalidades de su tiempo. Los Marani, además, sí quisieron sentirse y pensarse divos, aunque no siempre el mundo a su alrededor correspondiera a sus expectativas: un divorcio de percepciones que nos dice mucho sobre la historia de las mentalidades en los espacios y tiempos que les tocó vivir y desarrollar su quehacer artístico.

\section{ANDANZAS EUROPEAS}

Girolamo Marani nació en Italia entre 1744 y $1745,{ }^{4}$ en el entonces ducado de Milán. Fue de oficio bailarín, coreógrafo y, como entonces se decía, maestro de danzar. No hay noticias más precisas de su lugar de nacimiento ni, casi, de su procedencia familiar. Al parecer su padre se llamó Jacopo o Giacomo (más tarde erróneamente castellanizado en México como Joaquín) y su madre Marta Questa (o Chesta tal vez, si nos guiamos por la fonética). ${ }^{5} \mathrm{He}$ encontrado una referencia a una tal Mariana Mariani, también bailarina, en $1750,{ }^{6}$ cuando Girolamo tendría unos cuatro o cinco años. A lo mejor fue una tía u otra pariente: se trataba, finalmente, de un oficio familiar.

El nombre de Girolamo Marani en su dramatis persona de bailarín aparece por primera vez (a mi leal saber y entender) en 1762, cuando tendría unos 17 años. Aparece en una fuente análoga a la que contiene el nombre de su posible pariente: el libretto de una

${ }^{4}$ Según el Padrón de Extranjeros de Cádiz, en 1773 tiene 28 años (Archivo Histórico Municipal, Cádiz, AHMC, Padrones, L. 1007, fol. 181r), y según los examinum matrimoniorum de su boda, en 1763 tiene 19 (Archivio Storico del Patriarcato, Venezia, ASPV, Examinum matrimoniorum, vol. 263, fols. 172v y 174v), lo cual nos deja con un año de margen de incertidumbre.

${ }^{5}$ Aspv, Examinum matrimoniorum, vol. 263, fol. 172v; Archivio Parrocchiale di San Luca, Venezia, APSL, Registro dei Matrimoni in S. Luca dall'anno 1733 al 1773, vol. v, fol. 121r; AGN, Genealogías, C-YP P-RF R-64, fol. 25r.

${ }^{6}$ Aparece en el elenco de bailarines de Amore in tarantola. Dramma giocoso per musica (Venezia: Modesto Fenzo (impresor), Teatro San Moisè, 1750), 5; Taddeo Wiel, Teatri musicali veneziani del Settecento. Catalogo delle opere in musica rappresentate nel secolo XVIII a Venezia (Venezia: Arnaldo Forni, 1897), n. 524. 
ópera puesta en escena en Venecia. Stefano Locatelli habla de la "abnorme proliferazione della librettistica"7 (61) en el siglo XVIII. Existía una conexión evidente entre la impresión del libreto y la representación, ya que los datos de esta última aparecen en el libretto, a menudo vendido en el teatro mismo, contextualmente a la performance. Los gastos de imprenta eran pagados por los empresarios teatrales, y el pequeño formato (de bolsillo, diríamos hoy) obedecía a razones económicas y prácticas. A menudo se leían ahí mismo en el teatro, mientras se desarrollaba la representación; después cobraron vida autónoma como textos, gracias en buena medida al coleccionismo particular.

Gracias a ese auge de los libretti impresos, muchos de los cuales han llegado a nuestros días en óptimo estado de conservación, sabemos que entre 1762 y 1771 la presencia de Girolamo Marani en Venecia fue costante. Su nombre aparece en varios de los libretti de representaciones en algunos de los principales teatros de la ciudad, a saber, el Giustiniani (San Moisè), el Vendramino (San Salvatore), el Grimani (San Samuele), el San Benedetto. Venecia en su opulento esplendor lucía, entre otras actividades, una vida cultural y social animada, de la cual el teatro, confiado al mecenazgo de unas cuantas familias notables, era parte muy importante. Era la época cuando el dramma per musica, uno de los nombres de la ópera italiana, se afirmaba como el género teatral más de moda, en el que los bailes tenían gran importancia. Venecia era uno de sus foros principales. Muchas óperas se estrenaban allí para luego llegar a otras ciudades en Italia y en Europa. La riqueza que las mismas representaciones teatrales ostentaban queda consignada, por ejemplo, en un inventario de vestuario que probablemente se refiere al teatro San Benedetto y menciona un Marani que con toda probabilidad es nuestro Girolamo. El inventario nos deja imaginarlo en variaciones de atuendos de seda de muchas lentejuelas y variados adornos, y de pueblerino, y a la francesa, todo lo cual se hizo con "mayor magnifi-

${ }^{7}$ Stefano Locatelli, Edizioni teatrali nella Milano del Settecento. Per un dizionario biobibliografico dei librai e degli stampatori milanesi e annali tipografici dei testi drammatici pubblicati a Milano nel xviii secolo (Milán: ISU Università Cattolica, 2007), 61. 
cencia que lo normal", ${ }^{8}$ es decir, del derroche de lujo ya acostumbrado en las representaciones operísticas de la época.

El inventario habla de "Marani y su esposa", quien es también bailarina. Se trata de Teresa Pierantoni, quien desde la primera aparición aquí registrada, en 1762, es compañera de trabajo de Girolamo. En junio de 1763 aparece como "Teresa Pierantoni Marana”, efectivamente, se habían casado el 24 de abril de 1763 en la parroquia veneciana de San Luca, la parroquia de residencia de ella, como se acostumbraba. ${ }^{9}$ Teresa, originaria de Florencia e hija de un tal Michelangelo, tenía 16 años, tres menos que Girolamo, habría nacido alrededor de 1747. En los Examinum matrimoniorum, los papeles previos a la celebración de la boda, podemos leer, en parte, la historia de su romance. Cuenta Teresa:

Arrivò intanto a notizia di mio patrigno che avevo qualche inclinazione per detto Girolamo, e più volte mi disse che non lo ricevessi in casa, perché non poteva spendere, vivendo anch'esso della sua professione di ballerino, e più ancora soggiungeva che ricevessi in casa le sole persone che potevano spendere. [...] Girolamo veniva più frequentemente in casa; quando una sera, essendo noi soli in camera, e li miei genitori a letto, mi disse voler venire a dormire assieme con me, al che, avendo io resistito, finse partire, ed io, entrata di nuovo nella mia camera, mi coricai, e viddi ad un tratto uscire di sotto al letto il detto Girolamo, a cui, per il grande amore che gli portavo, non potei negare che venisse nello stesso letto, ed in quella notte mi deflorò. Ora che ho sofferto il danno della perduta verginità, e dovendo il detto Girolamo partire per Genova, vorrei esser assicurata coll'unione maritale, affinché non mancasse al suo dovere. ${ }^{10}$

Algo de enredo entremesil tiene la ocultación del galán debajo de la cama, la pretendida inocencia de la enamorada, el simpático jueguito espacial entre abajo y arriba de la cama misma: tal vez la narrativa de Teresa delata la influencia del mundo teatral que es parte de

\footnotetext{
${ }^{8}$ Archivio di Stato, Venezia, ASv, Inquisitori di Stato, 914, s/f.

${ }^{9}$ APSL, Registro dei Matrimoni in S. Luca dall'anno 1733 al 1773, vol. v, fol. 121r.

${ }^{10}$ ASPV, Examinum matrimoniorum, vol. 263, fols. 174r-174v.
} 
su vida cotidiana. Consumado indebidamente el amor, ahora les urge casarse, porque Teresa no puede quedar desprotegida, ni tampoco a la merced de un padrastro quien, al parecer, hubiera preferido que su pupila escogiera pretendientes más acaudalados. Amén de los insinuados sinsabores de Teresa con su padrastro, Girolamo alega que debe salir por trabajo a Génova. No he podido rastrear el libretto de esa representación, sin embargo, la afirmación encaja con lo que parece ser su estilo de vida por aquellos ańos: afincado en Venecia, saliendo de vez en cuando a trabajar a otra plaza teatral italiana o europea. Girolamo y Teresa están en apuros porque para casarse hay que presentar certificados de soltería, ellos no los tienen y les falta tiempo para las diligencias necesarias para conseguirlos de sus respectivos lugares de origen. Finalmente, les toca suplir la falta de papeles con un desfile de testigos que rinden declaración de que los conocen y saben que no cometen bigamia. Entre los testigos se encuentran compańeros de trabajo del teatro, siendo, como es bastante natural, el círculo social en el que se mueven: por ejemplo, Francesco Ceni, florentino, profesor de música; Giuseppe Mazzucchelli, milanés, violinista. La condición social bastante humilde de un bailarín de la época se trasluce claramente del recuento de Teresa: su padrastro se opone a su relación con Girolamo porque quiere que ella sólo se relacione con hombres "que pudieran gastar", y Girolamo Marani "no podía gastar, viviendo él también de su profesión de bailarín”. En los trámites de la boda se perfila también otro problema, que acompañará a los Marani toda su vida: las dificultades burocráticas que acompañan la relativa informalidad de su situación vivencial, el desarraigo territorial propio de su condición de cómicos de la legua (por mucho que trabajasen en teatros oficiales y de mucho prestigio), con respecto a los requerimientos legales de los lugares donde les tocó morar. Una especie de "sin papeles" ante litteram, expresión de nuestros tiempos para nómadas de antaño. En México, unas décadas después, llegarán a ser una suerte de clandestinos, como tales susceptibles de chantaje laboral.

Todavía les faltan a Teresa y Girolamo unos cuantos horizontes intermedios antes de llegar a América. Al final de la década de 1760 deciden abandonar Venecia, después de una presencia continuada 
desde 1762. En el otoño de 1769 aparecen en tres representaciones en Turín, una en Milán en 1770, y posiblemente vuelvan fugazmente a Venecia en 1771: aparece un tal "Girolamo Milani" actuando en Carnaval en el teatro San Moisè, y es muy probable que fuera él, siendo tan frecuentes las grafías erratas de su apellido. Cabe señalar que las representaciones de Turín marcan un hito en la carrera de Girolamo: ya deja de aparecer como simple ejecutante para volverse coreógrafo y director, papel que ya no abandonará. Ya en algunos libretti relativos a representaciones anteriores en Venecia, entre 1763 y 1765 , su nombre aparecía entre los ejecutantes, pero resaltado tipográficamente, lo cual habla de su habilidad y fama: Girolamo se perfila como una de las figuras principales del baile de ópera en la Serenissima en esos años.

Desde 1772, sus nombres sólo aparecen fuera ya de Italia. No conocemos las razones que los llevaron a dejar la lucida plaza de Venecia, sin embargo, podemos vislumbrar una inquietud existencial básica, implícita de cierta manera en su profesión: los espectáculos por su naturaleza tenían y tienen que circular, y así los artistas. En el siglo XviII se puede trazar un circuito, una ruta europea de ciertos espectáculos teatrales musicales y dancísticos, que, desde las plazas italianas importantes y de moda, como Venecia, salían a recorrer otras cortes, ciudades y países. Podemos además pensar que, como muchos otros, los Marani estuvieran en búsqueda de un porvenir mejor: no eran ricos ni mucho menos, y las espléndidas galas que llegaron a lucir en las tablas, la fama y el prestigio que por momentos gozaron, no correspondían a una situación financiera desahogadamente estable. Eran personas que constantemente luchaban por ganarse la vida con su arte y oficio (más algún ocasional negocio). Cada salida, cada mudanza habría ido acompañada de sueños y emociones, planes y expectativas que no siempre se cumplían, en una trayectoria vital cuyo horizonte siempre fue móvil. La vida de la familia Marani parece haberse desarrollado bajo el signo de la persecución de ese horizonte, siempre dispuestos a empacar y moverse hacia donde se fuera perfilando. Sólo podemos imaginarnos las conversaciones de Girolamo y Teresa en la víspera de algún nuevo viaje, las dudas, las angustias, las esperanzas, los sueńos de fama y fortuna. 
A estas alturas, además, Girolamo y Teresa ya tienen hijos que mantener. De su primogénito, Federico, hay pocas noticias y algo contradictorias. Aparece como "Federico Marana" en el padrón de extranjeros de Cádiz de 1773, con cuatro años de edad, así que habría nacido como en 1769. El mismo padrón consigna que es "de Palermo", ${ }^{11}$ donde a lo mejor nació porque sus padres se encontraban dando alguna función de la que no tengo noticia hasta ahora. Palermo se encuentra algo lejos de su circuito de trabajo habitual en el norte de la península italiana, más lejos que Praga y Viena, adonde los Marani ya habían salido; sin embargo, es muy probable que eso no les hubiera impedido, ni aun estando Teresa embarazada, que aceptaran una súbita propuesta de trabajo en la sureña Palermo. La única otra mención que encontré de Federico fue la de su trágica muerte en el gran y sonado incendio que cinco años más tarde, el 12 de noviembre de 1778, destruyó el teatro de Zaragoza, en España. El infortunio dejó un saldo de 77 fallecidos, entre los cuales estaba "Federico Marana, soltero, hijo del primer baylarín". ${ }^{12}$ La anotación "soltero" es algo extrańa para un niño que, si creemos al padrón de Cádiz, debía tener unos 9 años. Después, telón de silencio. En ningún otro de los documentos que he llegado a consultar aparece el nombre de Federico, ni siquiera cuando Girolamo, ańos después, por razones diversas, emprende el recuento de su historia profesional y familiar.

Los otros hijos de Teresa y Girolamo ya no nacieron en Italia. Antes de establecerse en España, donde permanecerán unos 12 ańos, los Marani aparecen en Lisboa en el Carnaval de 1772, bailando en no sabemos cuáles de las "tragedie e commedie da una compagnia portughese detta Sem Cabeça", ${ }^{13}$ al parecer en el Teatro do Bairro Alto. ${ }^{14}$ De Lisboa se fueron a Cádiz, donde aparece costancia

${ }^{11}$ AHMC, Padrones, L. 1007, fols. 180v-181r.

${ }^{12}$ AHPZ, J 002086/ 000006, fol. 48v.

${ }^{13}$ Roberto Verti, Un almanacco drammatico. L'indice de' teatrali spettacoli 1764-1823, vol. 1 (Pesaro: Fondazione Rossini, 1996), 72.

${ }^{14}$ José Sasportes no cita la fuente de este y otros datos, limitándose a anotar que proceden de "diversas cronologías publicadas sobre la danza y el melodrama en ese periodo, y de mi investigación personal” (la traducción es mía). José Sasportes, "Il Settecento portoghese rivisitato all'italiana”, en La danza italiana in Europa nel Settecento, ed. José 
de su presencia ya en octubre del mismo 1772. Cuando Teresa bailó en Lisboa estaba embarazada, y además con un embarazo avanzado: Juan Jácome Francisco Marani (en adelante, Juan) nacerá el 3 de abril de $1772 .{ }^{15} \mathrm{La}$ baja por maternidad no era, evidentemente, algo que Teresa y Girolamo pudieran permitirse: la función debía continuar. $\mathrm{Ni}$ tampoco podían retrasar sus planes de viaje y quedarse tranquilos en Lisboa esperando la llegada del bebé. Juan nace en Ayamonte, pueblo fronterizo entre Portugal y España, justo sobre el principal camino terrestre entre Lisboa y Cádiz, el que baja desde Galicia por toda la costa atlántica. ${ }^{16}$ No he encontrado otro rastro de los Marani en Ayamonte que deje pensar que pararan allí porque los contrataran para alguna función, ni por ningún otro motivo, así que me inclino a creer que Teresa entró en trabajo de parto y tuvieron que hacer una parada en su viaje. Transcurrió una semana entre el nacimiento y el bautismo de Juan, hecho no tan usual en esa época, lo cual pudiera indicar que el parto hubiera sido difícil y que madre e hijo necesitaran unos días de recuperación. Poco más de un año después, nace en Cádiz Juana Theresa Marani, en adelante Juana; a veces, ya en México, su padre le dirá, carińosamente, Chanita. La nińa nace el 4 de agosto de 1773 y es bautizada el 6, dos días después. ${ }^{17}$ Girolamo y Teresa tuvieron otros dos hijos más pequeños, José y María Antonia, de quienes he encontrado escasa mención más allá que en las listas de bailarines del Coliseo entre 1790 y 1806; hasta 1795, el nombre de José se encuentra con anotaciones:

Sasportes, 154 (Roma: Bulzoni, 2011). Interpelado en conversación personal (Lisboa, febrero 2014), alegó no recordar la fuente en cuestión, por tratarse de una investigación realizada muchos años antes. La referencia resulta, pues, dudosa y debe tomarse con reserva, aunque su coincidencia de fecha con el Indice de' teatrali spettacoli depone a favor de su veracidad. Al parecer, la mayoría de los documentos relativos a los teatros de Lisboa en aquellos ańos han ido a parar a la Biblioteca Nacional de Portugal y no se encuentran accessibles a consulta pública, por no haber sido aún ordenados y catalogados.

${ }^{15}$ Archivo Parroquial de Nuestra Señora de las Angustias, Ayamonte, APNSA, caja 9, fol. 353r.

${ }^{16}$ Véase el artículo de Máximo Diago Hernando y Miguel Ángel Ladero Quesada, "Caminos y ciudades en España de la Edad Media al siglo XvıII", En la España medieval (33) (2010): 347-382.

${ }^{17}$ Archivo Parroquial de la Catedral de la Santa Cruz, Cádiz, APCsc, libro 72, fol. 22r. 
"niño", "el chiquito". ${ }^{18}$ Se trata probablemente del mismo Joseph Marani que bailó en Puebla el 25 de enero de 1807 en el "drama histórico" Llegar a tiempo, según consigna el Prospecto publicado. Girolamo se volverá a casar (evidentemente ya viudo) con una tal Ignacia Diez, con quien tendrá otros dos hijos a la respetable edad de casi 70 ańos: José Gerónimo Espiridión, nacido el 16 de septiembre de 1812, y Gertrudis Teresa, nacida el 19 de noviembre de 1814. ${ }^{19}$ La niña llevaba el nombre de su primera esposa, lo cual nos hace pensar que él honraba su memoria, la memoria de la chica con quien se había casado en su primera juventud, la que era de su país y hablaba su lengua, la madre de sus primeros hijos, la compañera de vida y de trabajo que hasta embarazada no había dejado de bailar, y le había acompañado en todas sus andanzas europeas y en su aventura americana.

El padrino de los bautismos de Juan y Juana en España fue Francesco Marani, hermano de Girolamo, de profesión también teatrero -para más seńas, tramoyista-. Es evidente que durante un tiempo acompañó y trabajó con su hermano y su cuñada. Aparece también empadronado en 1773 entre los extranjeros habitantes y trabajadores de la Casa de la Ópera, en el número 88 y 89 de la calle del Empedrador, hoy Arbolí, del barrio de Santiago: una de las callejuelas del abigarrado centro de Cádiz, a escasas tres cuadras de la catedral y del mar. Años después, cuando Girolamo ya estaba en el Coliseo de México, Francesco trabaja en Madrid, también de "tramoyista y maquinista” ${ }^{20}$ El 3 de marzo de 1787 y 12 de abril de 1788 su nombre aparece en el Diario, en el elenco de la cartelera de las funciones anunciadas en el Coliseo de los Caños del Peral. ${ }^{21}$ En 1787 se le describe de la siguiente manera entusiasta: "Franchesco Marana, famoso por su mucha habilidad, conocida en los teatros más visibles

${ }^{18}$ Maya Ramos Smith, El actor en el siglo XVIII entre el Coliseo Nuevo y el Teatro Principal (México: Escenología, Conaculta, INBA, 2013), 178-187.

${ }^{19}$ AGN, Genealogías, C-YP P-RF R-64, fol. 25r, y C-ZF P-OAH R-149, fol. 35v. En este último documento el apellido de la madre aparece como "Gui[e]z", sin embargo, me inclino a pensar que se trate de un error, por ser "Diez" un apellido más común y corriente en castellano.

${ }^{20}$ Biblioteca Nacional de España, Madrid, BNE, Fondo Barbieri, T/14016/219, fol. 1v.

${ }^{21}$ BNE, Fondo Barbieri, T/14016/232 y T/14016/219. 
de España y fuera de ella”. ${ }^{22}$ Es el único en el reparto que le merece al autor del texto ${ }^{23}$ una descripción de este tipo, todos los demás sólo aparecen escuetamente por su nombre y función. Francesco Marani debió ser uno de los tramoyistas de la tradición del teatro italiano, desarrollada a partir de acrobacias y escenarios típicos de la Commedia dell'Arte. Dichos saberes fueron heredados al teatro espanool por las últimas compañías de Truffaldini que trabajaron en Madrid, entre la corte y el teatro de los Caños del Peral, a principios del XVIII, como señala Fernando Doménech Rico: "Tramoyas y decorados a la italiana capaces de transformar un espacio vacío en cualquier lugar del mundo". ${ }^{24}$ Girolamo, ya estando en México y en apuros, hablará de Francesco como prueba de la fama y lustre internacional de la familia.

Los años en España parecen haber representado una época bastante próspera para la familia Marani, amén de algunos altibajos. Girolamo fue director del Teatro Italiano o Casa de la Ópera, de Cádiz entre 1772 y 1778, año en que empezó a trabajar también en el teatro de Zaragoza. Entre 1778 y 1784 estuvo más bien trabajando en Zaragoza, ${ }^{25}$ sin perder, sin embargo, el contacto con Cádiz.

${ }^{22}$ BNE, Fondo Barbieri, T/14016/219, fol. 1v.

${ }^{23}$ El documento T/14016/219 es una copia manuscrita de una nota periodística análoga a la que aparece en su versión original impresa en el documento T/14016/232; no tenemos manera de averiguar si Barbieri la alteró al copiarla. Agradezco a Cristina Diez Rodríguez el haberme proporcionado las referencias y reproducciones de estos documentos del Fondo Barbieri.

${ }^{24}$ Fernando Doménech Rico, Los Trufaldines y el Teatro de los Caños del Peral. La commedia dell'arte en la España de Felipe V (Madrid: Fundamentos, 2007), 312.

${ }^{25}$ Después del terrible incendio del teatro de 1778, en el que murió Federico Marani, Zaragoza no volvió a tener teatro en forma hasta 1799. Sin embargo, la actividad teatral prosiguió en otros espacios, como palacios particulares de familias notables y edificios públicos. Se consignan, por ejemplo, la casa de don Manuel Oña (“ynfanzón” involucrado en la administración de la ciudad, quien por lo mismo aparece seguido en los documentos notariales de Zaragoza entre 1778 y 1784) y la Lonja de las Casas Consistoriales. Aurora Egido, Bosquejo para una historia del teatro en Aragón hasta finales del siglo XVIII (Zaragoza: Institución Fernando el Católico, 1987), 55; Ángel Lasso de la Vega, Autores aragoneses del teatro antiguo español (Zaragoza: La Cadiera, 1951), 31. Aunque no he podido encontrar rastro documental no sólo de la presencia de los Marani en Zaragoza después del incendio, sino tampoco de la actividad teatral susodicha (ninguno de los que han escrito al respecto cita alguna fuente primaria), los indicios indirectos contenidos en los documentos relativos a la Posada del Caballo Blanco, que cito en detalle más 
Tenía ahí alguna cuestión financiera pendiente y tenía también, en sociedad con otros italianos, ${ }^{26}$ un negocio: la Posada del Caballo Blanco, en la esquina de las calles Aduana Vieja y San Francisco. La ubicación era muy favorable para un negocio de hospedería. San Francisco, por un lado, era y es una de las principales calles y arterias comerciales de Cádiz, desembocando en la plaza homónima. El callejón de la Aduana Vieja, estrecho como la calle del Empedrador y más corto, entronca con San Francisco desde el muelle de la desaparecida Puerta de Sevilla, a menos de dos cuadras del entonces edificio de la Aduana (hoy sede de la Diputación Provincial). La Posada del Caballo Blanco, como la Casa de la Ópera, estaba cerca del mar; de la otra orilla, la del puerto, uno de los puertos principales de Espańa y de Europa. Las posadas de los puertos suelen ser excelentes negocios, y tan era así la Posada del Caballo Blanco que, a finales de 1784 , unos pudientes del ramo, los hermanos italianos Domenico y Francesco Gippini, ${ }^{27}$ aceptaron de Girolamo Marani su parte de la posada en pago de una deuda. Girolamo tenía prisa porque otra vez se iba, al poco tiempo, y esta vez más lejos: "Sea notorio como yo, Gerónimo Marani, residente en esta ciudad y de próximo a hacer ausencia de ella a los Reynos de las Indias". ${ }^{28}$ Entre el teatro, la posada y la notaría, arreglando cuestiones y pendientes, quizás vendiendo cosas, quizás comprando otras, atando fardos, y demás diligencias del caso, podemos imaginar a Girolamo, Teresa y sus dos nińos de 12 y 11 años, moverse en el ajetreo y bullicio de la atareada ciudad

adelante, parecen apuntar a que los Marani pasaron esos años en la capital aragonesa. Ramos Smith afirma que "además de la compañía de Cádiz, Marani se hizo cargo, en 1778, de las de Zaragoza y Málaga”. Sin embargo, no he encontrado fuentes documentales al respecto. Maya Ramos Smith, La danza en México durante la época colonial (México: Conaculta, Alianza Editorial Mexicana, 1990), 91.

${ }^{26}$ Julio Ragazi, probable castellanización de Giulio Ragazzi, y los naturales de Cerdeña, padre e hijo, Josef y Thomas Patoni o Pattoni. Ambas grafías aparecen en diferentes puntos de los documentos y son plausibles en italiano; sus nombres originales eran, con toda probabilidad, Giuseppe y Tommaso.

${ }^{27}$ Los hermanos Gippini eran parte de una rica familia originaria de Orta, estado de Milán, dueña de varias posadas en Sevilla y en el Puerto de Santa María (cfr. Archivo Histórico Provincial, Cádiz, AHPC, Protocolos Notariales de Cádiz, vol. 3791, fols. 128r$164 v)$.

${ }^{28}$ AHPC, Protocolos Notariales de Cádiz, vol. 3,791, fol. 289r. 
porteña de angostas callejuelas y baluartes viendo al mar. Eran sus últimos días en España y en Europa. No sabemos si repararon en pensar que cabía la posibilidad que no iban a regresar nunca, ni qué sentimientos pudo haberles despertado. De todos modos, la emociones de la salida quizás esa vez fueron más intensas y encontradas para la familia Marani. Si, por un lado, el viaje mismo era largo, incierto y peligroso, por otro, la oferta parece haber sido excepcionalmente halagüeña: unos años después, Girolamo Marani contará, reivindicará, haber llegado a México por invitación personal del conde Bernardo de Gálvez, quien había sido gobernador de Luisiana y volvía a las Indias con el cargo de capitán general de Cuba. No he encontrado, hasta ahora, noticias ni acerca del encuentro entre Gálvez y los Marani, ni de las circunstancias exactas de dicha supuesta invitación. Digo "supuesta" porque hasta aquí no he encontrado huella documental que la compruebe, aunque la versión de Girolamo es compatible con otros datos: las fechas de viaje, el conocido interés de Bernardo de Gálvez por el teatro, ${ }^{29}$ la ausencia de la familia Marani en las listas de regulares pasajeros a Indias. La pública declaración de su inminente viaje, además, hace improbable que se hayan ido de polizontes, aunque de algo parecido se les acusará unos ańos después, ante su imposibilidad de exhibir una licencia $u$ otro documento que acreditara su legal pasaje y estancia en México. Si damos por ciertas las declaraciones de Girolamo al respecto, resulta interesante notar como la invitación personal de un personaje noble como Bernardo de Gálvez, que para el bailarín fue un motivo de lustre y orgullo, se convirtió en un arma de doble filo: a la muerte del virrey, los protegidos por su mecenazgo quedaban desamparados y desprotegidos. Si en un momento pudieron, por decirlo de alguna manera, saltarse los trámites burocráticos que los comunes mortales tenían que cumplir para el pasaje a las Indias, eso más adelante se tradujo en una vulnerable situación de limbo legal, al no tener papeles que justifiquen su lugar en la norma burocrática del mundo.

${ }^{29}$ Por ejemplo, como virrey de México promulgará un célebre reglamento para el teatro en 1786 (editado por Germán Viveros, Teatro dieciochesco de Nueva España (México: UNAM, 2010), 207-234. 
La escritura notarial de cesión de Girolamo a los hermanos Gippini tiene fecha de 21 de octubre de $1784 .{ }^{30}$ Ocho días después, el 29 de octubre, sale de Cádiz, con rumbo a las islas de Barlovento, la fragata de guerra Santa Águeda, al mando de Rafael Orozco, acompañada por la fragata comercial San Francisco de Paula alias La Constancia, para poder transportar todos los cuantiosos lujosos avíos que correspondían al viaje de un personaje ilustre. En la Santa Águeda zarpó, precisamente, el conde Bernardo de Gálvez, ${ }^{31}$ sin que aparezca, en ninguno de los expedientes que en diferentes archivos guardan constancia de ese viaje, el desglose de las personas que componían "su comitiva". ${ }^{32}$ Según consigna en su diario Francisco de Saavedra, intendente de Caracas y amigo del conde de Gálvez, su plan original era hacer escala en la isla de Trinidad de Barlovento, antes de llegar a La Guaira, para finalmente seguir rumbo a Cuba. Sin embargo, encuentran mal clima y arriban a Venezuela, ya sin pasar por Trinidad, al cabo de dos meses y medio de ajetreado viaje, el 14 de enero de 1785. Durante dos días hubo varias celebraciones públicas en Caracas y alrededores para la recepción del conde de Gálvez, y en la noche del 16 un baile en el que, quizás, Girolamo y Teresa participaron. El 20 de enero, una funesta noticia llega de Cuba que interrumpe los festejos: el padre de Bernardo, Matías de Gálvez, virrey de la Nueva Espańa, está agonizando. ${ }^{33}$ El conde decide apresurar su salida, y, según le contará a su buen amigo Saavedra en una carta que le enviará desde Cuba el siguiente 10 de

${ }^{30}$ AHPC, Protocolos Notariales de Cádiz, vol. 3791, fols. 289r-295v.

${ }^{31}$ AHPC, Hacienda, legajo 10,796, exp. 9: "Ymbentario de los navíos y otras embarcaciones, de guerra y fletadas, españolas y extrangeras, que salieron para los puertos de Yndias desde 1722 hasta el de 788"; Archivo General de Indias, Sevilla, AGI, Contratación, 2916, pliego 2: "Toma de razón de las generalas, ranchos y equipages dados a la dotazión y guarnizión de la fragata de guerra Santa Águeda, con destino a las [...] yslas de Barlovento"; Archivo General de la Marina "Álvaro de Bazán”, Viso del Marqués (Ciudad Real), AGMAB, 4...: "Expedición a Veracruz transportando al virrey de Nueva Espańa conde de Gálvez y regreso desde aquel puerto al de Cádiz, con registro de caudales, conduciendo al mismo tiempo la viuda del anterior virrey Matías de Gálvez"; AGMAB, 2235/42: "Estado de salida de la fragata Santa Águeda de Cádiz".

${ }^{32}$ AGI, Contratación, 2916, pliego 2, fol. 49r.

${ }^{33}$ Francisco de Saavedra. Los decenios (Autobiografía de un sevillano de la Ilustración), ed. Francisco Morales Padrón, 254-255 (Sevilla: Excmo. Ayuntamiento, 1995). 
febrero, se entera de la muerte de su padre en una escala en La Aguadilla, Puerto Rico. ${ }^{34}$

El estado de luto reciente de Bernardo de Gálvez seguramente impidió que se realizaran en Cuba grandes festejos de recepción con bombo y platillo, con los acostumbrados espéctaculos, saraos y bailes, en que, con toda probabilidad, los Marani hubieran lucido sus artes. Una visita a los archivos y bibliotecas de Cuba no ha arrojado indicios de su paso por la isla. Tanto Gálvez como, presumiblemente, los Marani pensaban ir a residir a Cuba, mas en Cuba terminaron quedándose muy poco tiempo: menos de cuatro meses, hasta que Bernardo de Gálvez recibió el nombramiento de virrey interino de la Nueva España, para cubrir el que había sido el puesto de su padre. La fragata Santa Águeda, con el mismo comandante, zarpa de Cuba el 16 de mayo de 1785 y arriba al puerto novohispano de Veracruz el 25 del mismo mes..$^{35} \mathrm{La}$ familia Marani ha llegado a México, su nueva, definitiva, morada.

\section{EL SUEÑO AMERICANO}

El nombre de Girolamo Marani aparece por primera vez a principios de junio de 1786 en los papeles administrativos que se conservan del Coliseo de la Ciudad de México, siendo el asentista del teatro Manuel Lozano. ${ }^{36}$ El Estado que manifiesta las tonadillas, seguidillas, saynetes y suxetos que deven cantarlas en la próxima benidera semana que empieza el lunes 5 de junio de 1786 lleva una Nota, probablemente de puño y letra del mismo asentista, que dice: "El vayle del jueves y domingo será el que se le mande hacer a Marany [...] y los miércoles y sávados se ensayan los vayles en la escoleta”. ${ }^{37} \mathrm{La}$ disposición hace pensar que Marani se acababa de incorporar al per-

${ }^{34}$ Archivo de la Compañía de Jesús, Cartuja de Granada, fondo Saavedra, caja 14, exp. 107 (reproducción facsimilar en Manuel Olmedo Checa y Francisco Cabrera Pablos, Bernardo de Gálvez y su tiempo, p. 41, http://www.asociacionbernardodegalvez.es/ art/bernardo-de-galvez-y-su-tiempo.php (Fecha de consulta: junio de 2014).

${ }^{35}$ Gazeta de México, núm. 39, martes 7 de junio de 1785, 316.

${ }^{36}$ Maya Ramos Smith, El actor en el siglo XVIII, I 76-I77.

${ }^{37}$ Biblioteca Nacional de México, Fondo Reservado, México, BN-Fr, ms. 1,411 Asuntos de Teatro, fol. 78r. 
sonal del Coliseo, más o menos al año de haber desembarcado en México; quizás antes haya vivido de puro mecenazgo palaciego, y quizás al virrey Gálvez (que en julio del mismo año cayó gravemente enfermo y en noviembre murió) se le acabó el interés, el gusto o el capricho, no lo sabemos. La referencia a los ensayos retoma los artículos del 18 al 20 del reglamento de teatro promulgado por el mismo Gálvez en el año en cuestión de $1786,{ }^{38}$ artículos que a su vez reflejan la preocupación ilustrada de la época por reformar el teatro en el sentido de su depuración y profesionalización. Este mismo espíritu trasluce en otro de los documentos archivados entre los papeles del Coliseo de México, que menciona la contratación de Girolamo Marani como medida tomada en ese sentido y garantía de calidad. Se trata de una carta fechada 17 de abril de 1790, año en que Marani asumió, aparte de los cargos de maestro de danzar y primer bailarín, el de asentista del teatro, cargo que mantendrá hasta 1792. La carta no tiene firma; es probable que sea de la autoría de alguno de los jueces del teatro de la época, por ejemplo, Cosme de Mier y Trespalacios. Su planteamiento da cuenta de cómo las autoridades encargadas del teatro en México participan de las inquietudes de los intelectuales espańoles, que a su vez responden a cierto clima general propiciado por la estética ilustrada y neoclásica. Por un lado se ensalzan las glorias de la historia del teatro español y se reivindica su lugar en el contexto del teatro europeo; por otro, se critican sus "extravagancias" y se aboga por un teatro educativo, que fomente el ejercicio de las virtudes. El verbo ilustrar, variadamente declinado, es uno de los hilos conductores que estructuran el texto y el subyacente discurso. Girolamo Marani y su familia se mencionan nada menos que como ejemplo de la culminación de ese proceso de ilustración del teatro en México, como garantía y promesa de calidad de los espectáculos, como éxito de la "discreción y particular tino" del virrey Juan Vicente de Güemes Pacheco y Padilla, segundo conde de Revillagigedo, en sus gestiones en favor de las artes escénicas:

${ }^{38}$ Germán Viveros, Teatro dieciochesco, 217-218. 
$\mathrm{Al}$ paso que se ha ido extendiendo la inclinación a los teatros (dice un erudito savio de nuestra nación), se ha aumentado cada día más el gusto en nuevas obras con el objeto de ilustrar la dramática. [...] Deve convenirse en que todas las declamaciones contra el teatro espańol pueden convertirse también contra el de las demás naciones, [...] sin que por esto todo govierno ilustrado, como el de nuestra Espańa, deje de poner freno a la livertad tumultuosa de los teatros en todas sus partes, a fin de que en ellos se observe la regla principal de la dramática, cual es la honestidad y moderación como primera y sagrada ley de los teatros, destinados principalmente a la corrección de los vicios y a la instrucción del pueblo; al alivio de la frágil naturaleza humana por medio de un honesto recreo, que, divirtiendo los negocios más graves a los concurrentes y entreteniéndolos por algún tiempo en un ocio dulce y suave, los haga después más prontos y diligentes para las fatigas y para el exercicio de maiores virtudes. [...] La discreción y particular tino de Su Excelencia supo disponer las cosas de modo que voluntariamente hizo cesión y traspaso el dicho actual asentista ${ }^{39}$ al que lo fue de el teatro de Cádiz, Gerónimo Marani, que, con su familia, se halla establecido en este reino, con cuio solo hecho ha devido esperarse una considerable mejora en esta pública diverción. Desde luego se ha visto verificado este concepto, pues, sobre el aumento que ha recivido la compañía de farsantes en el número y en la calidad de sus individuos, se hallan más dotados en sus sueldos, con lo que, estándolo competentemente, pueden vivir con desahogo respectivo, presentarse en las tablas con proporcionada decencia, y, por consiguiente de no tener que pensar en su subsistencia, dedicarse al completo desempeńo de sus obligaciones. La horquestra se ha formado con los profesores mejores que aquí ay, cuales son los de la capilla, de la catedral, y los de los regimientos. ${ }^{40}$

Este tipo de reconocimientos debe evidentemente haber reforzado la idea de Girolamo y su familia acerca de su calidad de divos, y su condición de indispensables para el Coliseo. Sin embargo, no siempre esta imagen pudo sostenerse a lo largo de toda su carrera en México; al revés, hubo momentos en que la discrepancia entre las

${ }^{39}$ Manuel Lozano, quien fue el asentista del Coliseo inmediatamente precedente a Marani. Maya Ramos Smith, El actor en el siglo XVIII, 178.

${ }^{40} \mathrm{BN}-\mathrm{FR}, \mathrm{ms} .1,410$ Asuntos de teatro, fols. $151 \mathrm{r}-155 \mathrm{r}$. 
declaraciones de intentos expresadas en esta carta y las condiciones reales del contexto derivó en problemas más o menos graves. La dotación de sueldos no siempre fue de satisfacción de los actores, así como no lo fueron varias otras de las condiciones obligatorias de trabajo.

El conflicto mayor que estalló entre los teatreros del Coliseo y el mismo virrey Revillagigedo en 1794 fue un caso ejemplar y paradigmático. Hay abundancia de documentación al respecto de este caso, y también ha merecido bastante atención por parte de los historiadores del teatro en México. ${ }^{41}$ Girolamo Marani jugó un papel estelar en el asunto, escribiendo una carta donde se lo tomaba muy en serio, con todo el orgullo de alguien que se siente más que importante, indispensable, el orgullo de quien se percibe a sí mismo como un gran profesional, más aún, una estrella:

Soy natural de Italia, fui conducido a México a solicitud del virrey conde de Gálvez, y no embargado como los que llaman polizones. ${ }^{42}$ Vine en efecto con mi mujer y nuestros hijos, en la esperanza de mejorar mi fortuna, abandonando la que lograba en Cádiz, como bailarín principal de su Coliseo. Al principio me ajusté en 4,000 pesos, incluyendo en ellos a mi mujer y a mis hijos. Muerto aquel virrey busqué mi vida en otros pueblos, como las ciudades de Santiago de Querétaro y la Purísima Concepción de Celaya, y al fin volví, también solicitado. Últimamente el mayordomo del Hospital de Naturales ${ }^{43}$ me solicitó para nuevo ajuste, pero era tan bajo el que me proponía que me fue imposible admitir, y le hice mis proposiciones, por las cuales se me reprendió, graduándolas de excesivas. Después se me mandó presentar la licencia con que vine a este reino, y que, no habiéndola, se me haría restituir a mi patria. [...] Yo, por la Divina Misericordia, no nací esclavo; de consiguiente, no me parece soy digno de expulsión

${ }^{41}$ Principalmente Dallal, Olavarría y Ferrari, Ramos Smith.

${ }^{42}$ Fenómeno, por otra parte, bastante común. En Cádiz, por ejemplo, se encuentra archivado el expediente de un caso de tráfico de polizones que involucró el Colegio Seminario de Sant'Elmo de Sevilla en 1784. El escándalo estalló porque a Vicente Hermoso, uno de los embarcados en calidad de supuestos colegiales santelmistas, había "venido su mujer desde Madrid reclamándolo" (AHPC, Hacienda, legajo 10,798, exp. 14, fol. 2r).

${ }^{43}$ Joseph del Rincón, quien desempeñó también la función de asentista del teatro. Maya Ramos Smith, El actor en el siglo XVIII, 182-183. 
sin haber cometido delito que lo exige, como no lo es el que no me acomode a lo que se quiere, pues esto es libre en todo individuo de la república, al modo del que compra y vende. Yo no tengo más mercaderías ni peculio que el trabajo personal de mi habilidad: si, vendiéndolo a la pública utilidad, no acomoda el precio que estimo correspondiente a mi manutención y la de mi familia, me quedaré reducido a cultivar el pobre rincón de la misma finca que ya me tiene arraigado. ${ }^{44}$

Antes que nada, podemos notar cierta inclinación de Girolamo Marani para reformular y ajustar la historia de su vida según mejor le conviene. En noviembre de 1784, cuando -según parece- viaja a México en la comitiva del conde de Gálvez, él ya no trabajaba en el Teatro Italiano, o Casa de la Ópera, de Cádiz, que, dicho sea de paso, no era "el Coliseo" de la ciudad, sino uno de los teatros que ahí existieron. Después de su actuación en el Carnaval de 1778, Girolamo y Teresa Marani ya no aparecen en los elencos del teatro que han llegado hasta nosotros. ${ }^{45}$ Según trasluce de los documentos relativos a la gestión del negocio de la Posada del Caballo Blanco, ${ }^{46}$ a principios de 1778 "Gerónimo Maranni, residente en esta ciudad de Cádiz, de exercisio baylarín" estaba "próximo a hazer viaje a la de Zaragoza, de primero de aquel theatro de óperas"; ${ }^{47}$ por lo mismo, dejaba a los hermanos Gippini como administradores apoderados de su parte del negocio de la posada "por tiempo y espacio de seis años, que principiaron a contarse, el día primero de enero del co-

${ }^{44}$ Guía de forasteros, núms. I-7, pp. 1, 10. Cito esta carta de una fuente secundaria porque me ha sido imposible rastrearla en los documentos del Coliseo. Maya Ramos Smith, La danza en México, 112-113. Ahí se indica que la carta está en BN-FR, ms. 1413 Asuntos de Teatro, fols. 28-29; sin embargo, me consta que en ese lugar, a la fecha de mi consulta (noviembre 2013), el documento no está. Tampoco lo he podido rastrear en ninguno de los otros archivos que he consultado. La cantidad de referencias me hace pensar que el documento efectivamente existe o existió, sin embargo, pienso que se ha perdido o alguien lo ha sustraído indebidamente.

${ }^{45}$ Roberto Verti, Un almanacco drammatico, 275.

${ }^{46}$ AHPC, Protocolos Notariales de Cádiz, vol. 1,197, fols. 17r-25v; vol. 3,791, fols. 289r-295v.

${ }^{47}$ AHPC, Protocolos Notariales de Cádiz, vol. 1,197, fol. 18r. Girolamo y Teresa efectivamente aparecen en el elenco del teatro de Zaragoza "nella primavera 1778" (Roberto Verti, Un almanacco drammatico, 300). 
rriente de la fecha”. ${ }^{48}$ Domingo/Domenico Gippini firma la renovación de la compañía por otros seis años el quince de enero de $1784 .{ }^{49}$ En la escritura de cesión definitiva en 1784 se menciona el "travajo que havían de tener los dos primeros mis acreedores [los hermanos Gippini] en la administración, dirección y manejo de la compañía [...] durante el tiempo de la ausencia que efecieté [sic] a Zaragoza". ${ }^{50}$ Todo apunta a que Girolamo Marani no estuvo residiendo en Cádiz, sino más bien en Zaragoza, entre 1778 y 1784.

Tampoco la vida en España había sido pura miel sobre hojuelas para el bailarín y su familia: las dificultades financieras siempre estaban al acecho. Entre septiembre y noviembre de 1780, por ejemplo, Girolamo Marani trató de cobrar a Vizente Gerardi, quien había sido uno de los diputados del Teatro Italiano, ${ }^{51}$ la cantidad de diez $\mathrm{y}$ seis mil quinientos reales de vellón (uno mil y treinta pesos fuertes), que, alegaba, "me está deviendo en virtud de cierta contrata que tengo presentada en autos que penden en el Juzgado de la Guerra”. ${ }^{52}$ Dicha contrata resulta ser "por razón de mi salario y el de Theresa Pierantoni, mi muger, como tales baylarines del mismo [teatro]". ${ }^{33}$ Vizente Gerardi había sido uno de los cuatro ciudadanos "afectos a la menzionada diversión de óperas", quienes, "con la mira de que estta no faltte, y por hazerme vien y buena obra", ${ }^{54}$ en abril de 1769 rescataron de la bancarrota al entonces asentista del teatro, Joseph Darbricio. Entre otros gastos y deudas, "los rreferidos habrán de hazer de prontto, según ttienen promettido, [...] desembolsos para el pago de los alcanzes que [...] [a] yndividuos de la ópera, músicos, arrendamiento [...] y demás operarios ttengo adeudados". ${ }^{55}$ Girolamo Marani llevaba algo de tiempo esperando cobrar: en 1780

${ }^{48}$ AHPC, Protocolos Notariales de Cádiz, vol. 1,197, fol. 18v.

${ }^{49}$ AHPC, Protocolos Notariales de Cádiz, vol. 1,197, fol. 25v.

${ }^{50}$ AHPC, Protocolos Notariales de Cádiz, vol. 3,791, fol. 289v.

${ }^{51}$ AHPC, Protocolos Notariales de Cádiz, vol. 5,910, s/f [fol. 1r].

52 AHPC, Protocolos Notariales de Cádiz, vol. 3,486, fol. $341 \mathrm{r}$.

${ }^{53}$ AHPC, Protocolos Notariales de Cádiz, vol. 5,910, s/f [fol. 1r].

${ }^{54}$ AHPC, Protocolos Notariales de Cádiz, vol. 2,557, fol. 124v. Los otros diputados eran el conde Prasca, Franzisco Pagani (visita de la Real Aduana) y Franzisco Moerart (él y Gerardi eran "vezinos y del comercio" de la ciudad) (fol. 125v.).

${ }^{55}$ AHPC, Protocolos Notariales de Cádiz, vol. 2,557, fol. 125r. 
probablemente ya ni existía el Teatro Italiano como tal. Sus últimas funciones parecen haberse montado en 1778, aunque hay presencia documentada de artistas italianos en Cádiz, trabajando en otros teatros, por lo menos, hasta el carnaval de $1793 .{ }^{56}$

Para que se ocupe del cobro, Marani nombra, en calidad de representante legal con poderes amplios (lo cual sugiere, una vez más, que no se encontraba en Cádiz para atender el pleito personalmente), a Antonio Pizano, maltés, a cambio de un honorario de ochenta y cinco pesos fuertes. ${ }^{57}$ Un par de meses después, Marani firma un documento en que acepta de Vizente Gerardi un pago de ochenta y cinco y medio pesos, renunciando a seguir el pleito legal "para evitar gastos en un dilatado litigio, que no podía sufrir, y porque estaba próximo para ausentarme de esta ciudad". ${ }^{58}$ Girolamo firma el documento de su puño y letra, el nombre de Antonio Pizano ya no aparece. Apenas cubriría su honorario el cobro logrado de Vizente Gerardi, menos que la décima parte de la suma que había originalmente pretendido. Parece que el bailarín tuvo que darse una vuelta a Cádiz para atender el asunto, estando ya próximo a irse otra vez (¿de regreso a Zaragoza?).

Los intentos fallidos de cobros de pagos atrasados serán un problema que volverá a presentarse en la vida de Girolamo en México. Entre 1816 y 1817, por ejemplo, estará presentando una queja ante la Real Audiencia: "Gerónimo Marani, bailarín que fue de este Coliseo, dice que en el ańo de ochocientos catorce estuvo empleado en él, trabajando en su oficio. Se le quedaron debiendo por el señor don José Alegría ${ }^{59}$ doscientos sesenta pesos que repetidas veces ha cobrado sin lograr que se le paguen". ${ }^{60}$ Otro maestro de baile, Juan Eustaquio Medina, presenta una queja análoga al mismo tiempo. ${ }^{61}$

${ }^{56}$ Roberto Verti, Un almanacco drammatico, vol. I, 4-594; vol. II, 950-1,009.

${ }^{57}$ AHPC, Protocolos Notariales de Cádiz, vol. 3,486, fol. 341v.

${ }^{58}$ AHPC, Protocolos Notariales de Cádiz, vol. 5,910, s/f [fol. 1v].

${ }^{59} \mathrm{El}$ administrador del Hospital Real de Naturales y encargado del Coliseo entre 1792 y 1795 (Maya Ramos Smith, El actor en el siglo XVIII, 181-183).

${ }^{60}$ AGN, Indiferente Virreinal, caja 1,151, exp. 5, s/f [fol. 1r].

61 "Expediente sobre que se les satisfaga a los maestros baylarines del Coliseo, don Juan Eustaquio Medina y don Gerónimo Marani, los sueldos que se les restan del tiempo que sirvieron en dicho teatro por cuenta del Hospital de Naturales" (aGN, Historia, vol. 482, exp. 3, encabezado, s/f). 
En el expediente no hay resolución ni seguimiento a sus peticiones, al contrario, claros indicios de que no fueron atendidas. A Medina se le informa, con exquisita cortesía burocrática, que su demanda está en trámite, "presente para cuando se viesen las cuentas del señor Alegría [...] pendiendo este y otros créditos de la decisión de quién haya de lastarlos". ${ }^{2}$ Con Marani, el regente del Hospital, destinatario de repetidas solicitudes, ha sido verbalmente más explícito: "Solo de palabra me ha dicho que no le moleste, hasta que Alegría no dé cuenta de los caudales del Hospital". Y a nada parecen llevar sus sucesivas alegaciones, que sin más respuesta cierran el expediente: "Yo nada tengo que ver con esto, pues a quien serví fue al Hospital y este es quien deve pagarme, aunque el administrador no rinda ni dé las cuentas". ${ }^{63}$

A la luz de los documentos notariales relativos a su estancia en Cádiz, podemos afirmar que la narrativa de Girolamo Marani, que se describe abandonando la prosperidad gaditana por el honor de la invitación del virrey, resulta, cuanto menos, dudosa. Por un lado, todo parece indicar que ya no vivía realmente en Cádiz por esas fechas. Por otro, dicha prosperidad luce algo empañada: Girolamo cedió su parte entera de la Posada del Caballo Blanco a cambio de una deuda, pagándole así a los hermanos Gippini su labor de administradores apoderados, y tuvo cuando menos el problema de un cobro malogrado (y quizás más, de los cuales no he encontrado noticia). La prosperidad que sí hubo, tanto que le permitió participar en una sociedad comercial, no dejó, sin embargo, de ser precaria. Desde que gozaba de éxito en los teatros de moda de la glamorosa Venecia, Girolamo Marani "non poteva spendere, vivendo [...] della sua professione di ballerino"; en Cádiz la situación no cambió de manera estable y sustancial, ni tampoco en América. Lo cual no impidió que la percepción del bailarín de sí mismo respondiera más a sus sueños que a su realidad material y económica.

Con respecto a la gira de los Marani por los caminos de la legua en México, parece haber acontecido entre la segunda mitad de 1786

${ }^{62}$ AGN, Historia, vol. 482, exp. 3, fol. 2 r.

${ }^{63}$ AGN, Historia, vol. 482, exp. 3, fols. 3r-3v. 
y principios de 1790. En ese periodo, la familia no figura en los elencos del Coliseo, ${ }^{64}$ aunque no haya hasta ahora encontrado más datos acerca del itinerario y duración de su recorrido. Aquí el recuento de Marani no es descabellado: la enfermedad y muerte del virrey bien pueden haber significado un desamparo que le moviera a hacer lo que solía hacer en circunstancias análogas, es decir, irse con su oficio a buscar fortuna. Así que solicitó, en fecha desconocida, permiso para emprender camino. ${ }^{65}$ Girolamo Marani afirma que volvió a México solicitado, requerido ${ }^{66}$ No es imposible, ya que vuelve a aparecer en 1790, con la capacidad económica y el optimismo para hacerse cargo del Coliseo de México en calidad de asentista.

Unas frases, en particular, son las que detonan la cólera del virrey Revillagigedo:"Yo, por la Divina Misericordia, no nací esclavo; de consiguiente, no me parece soy digno de expulsión sin haber cometido delito que lo exige, como no lo es el que no me acomode a lo que se quiere, pues esto es libre en todo individuo de la república". El orgullo y la reivindicación de libertad de las palabras de Marani provocaron que Revillagigedo le recordara que se encontraba en un virreinato, no en una república:

Vista la respuesta dada por Gerónimo Marani, y la instancia y documentos que seguidamente presentó, hágasele comparecer y reprehéndasele con la maior aspereza, por las insultantes, poco regulares y descomedidas expresiones vertidas en su escrito. Apercíbasele de que, si en lo sucesivo no mejora su modo de producirse, será tratado con todo el rigor de que sea digno. Oblíguesele a que declare quién le formó el expresado escrito, hágase una formal y verídica justificación de la propiedad que tenga sobre la corta finca rústica de que habla, averígüense los medios de que se ha valido

${ }^{64}$ Maya Ramos Smith, El actor en el siglo XVIII, 177-178.

${ }^{65}$ BN-FR, ms. 1411 Asuntos de Teatro, fol. 20r.

${ }^{66}$ Ramos Smith consigna que Girolamo fue asentista en Querétaro "durante la temporada 1787-1788”, sin embargo, sin citar fuentes documentales. Tanto Ramos Smith como María y Campos afirman que Marani volvió a la Ciudad de México porque fue solicitado, sin tampoco haber yo encontrado fuentes que lo comprueben. Maya Ramos Smith, La danza en México, 98; Armando de María y Campos, Entre cómicos de ayer. Apostillas con ilustraciones sobre el teatro en América (México: Arriba el Telón, 1949), 20. 
para adquirirla. Y, últimamente, hágasele entender que con oportunidad resolveré lo que convenga en quanto a que se traslade a España con su familia, respecto a que se halla en este reyno sin la correspondiente Real Licencia, cuia falta se le disimulaba solo por el beneficio del público, pero que, cesando este, debe quedar sin efecto aquella tolerancia. ${ }^{67}$

Ramos Smith reflexiona: "A Revillagigedo le desagradó profundamente la dignidad con la cual Marani reclamaba la igualdad. Todo pensamiento que aludiera a los derechos del hombre parecía surgido de las ideas de la Revolución francesa, que el rey de España y sus representantes consideraban subversivas y peligrosas". ${ }^{68}$ Revillagigedo esgrime la falta de regular licencia de Girolamo y su familia, espada de Damocles suspendida siempre sobre su cabeza. Marani afirma su libertad de irse del teatro si el ajuste propuesto no le acomoda, Revillagigedo le recuerda que su presencia en el país depende única y exclusivamente del beneficio que representa para el público: si abandona el teatro, será expulsado de la Nueva Espańa. Acerca de la "corta finca rústica" que Girolamo describe en tono propietario, como refugio y medio de vida, el virrey implacable le intima que justifique no sólo la efectiva propiedad, sino también los medios que le permitieron adquirirla. El virrey no parece para nada impresionarse, ni siquiera tomar nota, más aún, ni siquiera menciona la justificación de Girolamo Marani por no contar con licencia, que Marani reitera una y otra vez, en varias declaraciones y documentos:

Comparecencia de Gerónimo Marani. En la Ciudad de México, a diez de abril de mil setecientos noventa y quatro, ante el mismo seńor juez del teatro, compareció Gerónimo Marani, y por ante mí el escrivano. Se le leyó e hizo saber de verbo ad verbum el expressado superior decreto, en lo que le toca, con la notificación que incluye. De que, entendido, dixo que no impetró licencia de su Magestad porque, estando avencindado en Xerez de la Frontera, se le ofreció pasar a Cádiz, donde concurrió con el exce-

${ }^{67}$ BN-FR, ms. 1413 Asuntos de Teatro, fols. 32r-32v.

${ }^{68}$ Maya Ramos Smith, La danza en México, 113-114. 
lentísimo señor don Bernardo de Gálvez, y Su Excelencia le instó para que se viniese a la Havana con su Familia, a que accedió; y, con efecto, se incorporó con la de Su Excelencia, acompañado de su muger e hijos. Por cuio motivo no puede exhibir la con que pasó a estos reynos. ${ }^{69}$

No tengo otras noticias de que los Marani se hubieran avencidado en Jerez (muy cerca de Cádiz) y que ahí se haya verificado el fatídico encuentro con el conde de Gálvez. Tal vez Marani, aunque (después de 1778) considerara terminada su relación laboral con Cádiz, resolvió residir de todas maneras cerca para justamente buscar una manera de viajar a América. Tal vez, por el contrario, otras razones lo llevaron a Jerez (también era una próspera ciudad comercial y seguramente tenía vida teatral) y fue inesperada la propuesta de Gálvez. Como sea, Girolamo tiene en un lugar especial dicho encuentro e invitación en su historia personal: es uno de los elementos que construyen su imagen de profesional serio, y más aún, de fama y reputación. Sin embargo, su presencia en México, que él quisiera ver protegida, amparada y legitimada por el recuerdo de una invitación personal del virrey próximo difunto, resulta más bien sujeta a no contrariar al virrey vivo y en funciones. Ha de haber sido una notable frustración ver como el privilegio aquel había sido tan frágil, trasformándose en una permanente fuente potencial de chantaje.

"Este año se me mandó pusiera algunos bailes que se me pagarían aparte: puse hasta once, y los cuatro no se me pagaron y de los siete se me hizo un fuerte rebajo. Vendí al mayordomo varias decoraciones y vestidos en 599 pesos, y solo me han dado ciento, y los restantes no se me quieren pagar", incluye Marani entre sus quejas. ${ }^{70}$ Está hablando de una relación tensa con el administrador del Hospital de Naturales, y encargado del Coliseo, Joseph del Rincón. Amén de la cuestión tristemente recurrente de los sueldos crónicamente atrasados, se manifiesta aquí una disputa acerca de decoraciones y vestidos que, vendidos por Marani a Rincón, no han sido, según el primero, adecuadamente pagados. Girolamo Marani salía

${ }^{69}$ BN-FR, ms. 1413 Asuntos de Teatro, fol. 28v.

${ }^{70}$ Guía de forasteros, núms. I-7, 10. 
en los tablados de la opulenta Venecia luciendo vestuarios "con mayor magnificencia de los normal”. Debe haber tenido en alta estima sus atuendos escénicos, parte imprescindible de su percepción de sí mismo, así como todos sus enseres profesionales. Sin embargo, la historia es suceptible de otras lecturas. Entres los intercambios de cartas y papeles que entretejen el pleito que nos ocupa, se encuentra precisamente una epístola de Joseph del Rincón, en la que, después de una prolija explicación de por qué no se le debe nada, saca a colación los dichosos enseres bajo una perspectiva bastante diferente:

Excelentísimo señor: si no tubiese la satisfacción de que a Vuestra Excelencia es constante la integridad con que me manejo en los encargos que el rey, y Vuestra Excelencia se ha servido conferirme, podría hoy estar lleno de temores a vista de una acusación tan asombrosa como la que se advierte en el escrito presentado por el bailarín Gerónimo Marani, que ciertamente me cubre de admiración. Tengo bien conocido el carácter de este hombre, y no estraño en él se condugese con tanta falsedad para instruir al tiempo de formarse el tal escrito. [...] Lo mismo sucede en quanto [a] aquello de las decoraciones y vestidos que dice me vendió, y sobre que pudiera extenderme aquí demasiado. Básteme asegurar a Vuestra Excelencia que no hubo tal venta, y por el contrario, estándome incomodando con esos enseres diariamente, hasta amenazarme con que si no se los pagaba en el tiempo y del modo que él quería los llevaría al baratillo, le contesté que cargase con ellos quanto antes, dando orden al tramoyista Juan Zúniga para que se los entregara en el instante que los pidiese. Arrepintiose de su pensamiento y hallá, como quiso y quando le pareció, llamó a un pintor, y entre este y él pusieron precios a las decoraciones; haciendo esto propio con la ropa por medio de un sastre no examinado, a quien tomó por instrumento para seńalar valores fantásticos, a pesar de decirle el mismo sastre que aquella operación no servía nada. En cuya inteligencia, buscó a un perdulario, que ni es sastre ni ha pensado serlo, para que le firmase el celebérrimo avalúo, con que se vio muy satisfecho. ${ }^{71}$

${ }^{71}$ BN-FR, ms. 1,413 Asuntos de Teatro, fols. 47r-51v. 
El vestuario magnífico de Marani queda en la posición de triques que estorban. Cuando hasta el dudoso sastre traído por Marani, sigue Rincón, se negó a suscribir los supuestos "valores fantásticos" que atribuía a las prendas de vestuario, Marani "buscó a un perdulario, que ni es sastre ni ha pensado serlo, para que le firmase el celebérrimo avalúo, con que se vio muy satisfecho". Aunque para Marani y su familia debió ser un asunto serio y angustioso, la enésima pérdida financiera, es difícil no reír frente al recuento de Rincón, con todo y aparición picaresca de un falso sastre suscriptor de fraudes. Una serie de atuendos brillantes y deslumbrantes pueden, bajo otra luz, ver su brillo ofuscado o desleído, y ver su condición de vestido de la gloria inopinadamente trocada por la de harapo estorboso. Miseria y nobleza, miseria e nobiltà, describen el conflicto constante en la trayectoria vivencial de Girolamo Marani y su familia, siempre en la cuerda floja entre el relumbre y las dificultades.

Finalmente, Marani y su familia aceptan reincorporarse al teatro acatando las condiciones de la administración, con una carta de Girolamo y su hija Juana fechada en 30 de abril de $1794 .{ }^{72}$ El virrey instruirá a Joseph del Rincón a que los admita, no obstante la oposición de este último. Los Marani se ven obligados a doblegar su orgullo y pedir su recontratación a las condiciones que sean. No será el último problema que tendrán con Joseph del Rincón, quien, unos meses después (el 17 de septiembre), se volverá a quejar con el siguiente virrey, el marqués de Branciforte. Juan y Juana Marani tendrán los papeles protagónicos en este nuevo sainete de vida teatral. Juan Marani se niega a ensayar el baile La conquista de México bajo la dirección de José María Morales. A la tercera vuelta, Joseph del Rincón, quien evidentemente presenciaba los ensayos, se desespera y toma cartas en el asunto:

Le insté a que bailase, que se lo mandaba yo. Se resistió por segunda vez, y volví a repetirle las mismas palabras de que yo se lo mandaba; y, ya muy descompuesto, se vino a mí respondiéndome atrevido que, por lo mismo

${ }^{72}$ BN-FR, ms. 1,413 Asuntos de Teatro, fols. 98r-98v. 
que yo se lo mandaba, no quería hacerlo. Esta insolencia exigía el que yo tomase ya otra providencia, para escarmentarlo y hacerle entender la subordinación con que debe manejarse. [...] A cuyas altaneras voces siguió con otras, acompañado de su hermana Juana, quien, entre lo que me gritaba, solo entendí que repitió lo que él había dicho acerca de que era tan bueno como yo, y que no llevaría a la cárcel a su hermano. Creía que, según me cercaron la familia de Marani, me expusiesen a un lance más sensible, y resolví voltear la espalda y hacer que cerrasen la puerta mientras buscaba quién lo asegurase a él y dar cuenta a Vuestra Excelencia. ${ }^{73}$

Es ya insoportable, cuenta Rincón, el carácter altanero y berrinchudo de los Marani: "Ya en otra ocasión he representado a este superior govierno a lo que llega el engreimiento de esta familia y su insufrible mala crianza" ${ }^{74}$ Dicho carácter, sigue el administrador, es especialmente dańino en el contexto del teatro, ya que "el mal ejemplo cunde más en los cómicos y bailarines que en otra clase de gentes, por las protecciones que siempre tienen, ya por su cara, ya por su habilidad, ya por otra cosa". ${ }^{75} \mathrm{Tal}$ aseveración deja clara la opinión general del administrador con respecto a los teatreros, postura que ha de haber hecho del Coliseo por esos años un ambiente de trabajo algo tenso y desagradable. No hay registro, finalmente, de si el virrey se haya dignado contestar a la queja del ofendido administrador, amén de que los Marani seguirán otro par de décadas en los repartos de bailarines del Coliseo. Ramos Smith describe a Joseph del Rincón como un "siniestro personaje que durante más de diez años habría de emplear todas sus energías en intrigar-por mezquinas razones económicas- contra los Marani y la compañía de bailarines" ${ }^{76}$ Es un retrato muy creíble, trazado por las mismas acciones documentadas del administrador. Sin embargo, la evidente mala leche de Rincón hacia los Marani no quita valor a su percepción del carácter de los mismos. Podemos percibir que se trataba de personas orgullosas, en actitud de defender y reivindicar su propio

\footnotetext{
${ }^{73}$ AGN, Historia, vol. 478, exp. 6, fols. 21r.-22r.

${ }^{74}$ AGN, Historia, vol. 478, exp. 6, fol. 22r.

${ }^{75}$ AGN, Historia, vol. 478, exp. 6, fol. 22v.

${ }^{76}$ Maya Ramos Smith, La danza en México, 107.
} 
valor y mérito, amén de esgrimir maneras al parecer vocales y ruidosas, como buenos italianos de tópica estampa. Mismas maneras, voceríos y ademanes que hicieron huir despavorido, de muy entremesil manera, al amedrentado y arrollado administrador del Coliseo. "Deberían haberse castigado soberanamente, para cortar sus punibles atrevimientos, haciéndoles que entendiesen la diferencia que hay de ellos a mí, aun cuando no tuviera bastoncito, ni el encargo de mandar", añade Joseph del Rincón en su vehemente protesta. ${ }^{77}$ En su visión, los Marani deberían reconocer y acatar su superioridad: una superioridad esencial, o cuando menos social, antes que relativa a las contingentes jerarquías de la administración del teatro. El orgullo de los Marani, sin embargo, no pudo acoplarse a semejante pretensión. Lejos de sentirse inferior a un pequeño burócrata (presumiblemente) criollo como Joseph del Rincón, lejos de sentirse inferior a nadie, sino todo lo contrario, Girolamo Marani llegó a nada menos que pregonar nobleza.

Esta vez, el casus belli no detona de un pleito laboral o administrativo en el teatro, aunque todos los protagonistas en el teatro hacen su vida. El 27 de agosto de 1792, Juan Marani, que tiene en ese entonces veinte ańos y meses, presenta ante la autoridad civil la petición de casarse, contra la voluntad de su padre, con una chica llamada Bárbara Álvarez. ${ }^{78}$ Felipa Mercado, la madre de la novia de Juan Marani, era en aquellos años primera cantarina del Coliseo y viuda del actor José Antonio Álvarez Gato, recién había fallecido en 1788. Felipa y José parecen haber tenido una historia en la legua, como Girolamo y Teresa, por lo que se sabe de sus andanzas antes de llegar a la compañía del Coliseo de la Ciudad de México. El 2 de agosto de 1786 se solicita su pronto regreso de La Habana, Cuba. ${ }^{79}$ De Maravatío, su pueblo de origen, a la Ciudad de México parece que llegaron, en fecha no precisada, de una manera bastante picaresca, pegándosele a don Alonzo Pando, un "mercader viandante" español que habían conocido en una noche de fandango: "Haunque se escusó y madrugó para venirce, lo alcanzaron marido y muger en el camino, que con

\footnotetext{
${ }^{77}$ AGN, Historia, vol. 478, exp. 6, fol. 22r.

${ }^{78}$ AGN, Civil, vol. 843, exp. 1, fol. $1 \mathrm{v}$.

${ }^{79}$ BN-FR, ms. 1411 Asuntos de Teatro, fols. 285r-286r.
} 
este motivo llegaron hasta México y aún estuvieron juntos ocho días en el mesón, hasta que se acomodaron en el Coliceo". ${ }^{80}$

¿Por qué Girolamo Marani habría de poner reparos a la boda de Juan y Bárbara? Los novios se conocen en el teatro, donde se habían conocido él y su Teresa unas décadas antes. Ambas familias pertenecían desde siempre al mundo de las profesiones teatrales, ambas habían llegado al Coliseo de la ciudad después de otras andanzas dentro y fuera de las fronteras novohispanas. Los chicos estaban en edad más que acostumbrada para casarse en su medio y época. Pese a todo, el orgullo de Girolamo Marani salió a relucir de una forma que quizás sorprendió a su misma familia. Girolamo emprendió la cruzada de demostrar que los Marani y los Álvarez no eran iguales. Ellos habían llegado de invitados en la comitiva personal del conde de Gálvez, no de pasajeros encajosos en la carreta de un mercader, por ejemplo. Y más. Argumenta Girolamo:

Aunque entre mi hijo y la Álvarez hay igualdad en la pobreza (por la que vendrán a ser dos miembros gravosos al Estado), pero no la hay en quanto a la calidad. La de mi hijo, con solo la notoriedad de que sus padres y todos sus acendientes nacieron en la Ytalia, en donde no hay mezcla de castas como en este reyno (y algunas reputadas por las leyes municipales de infames) tiene a su favor la presunción de limpieza de sangre. Así, es preciso que antes de todo justifique la Álvarez su calidad y la de sus padres, por sus partidas de bautismo y demás pruevas que en derecho corresponden, pues, siendo el objeto de la Real Pragmática evitar de todo punto los matrimonios entre desiguales, el manifestar que mi hijo y la Álvarez no los son deve ser todo el fundamento de su intención. ${ }^{81}$

Felipa Mercado le responde que, para empezar, a este caso no le incumbre la Real Pragmática:

El espíritu de esta real disposición se dirige a estorvar el que no se enbilescan las familias nobles con la mescla de otras infames y bajas. Nada de esto

${ }^{80}$ AGN, Civil, vol. 843, exp. 1, fols. 66r-66v.

${ }^{81}$ AGN, Civil, vol. 843, exp. 1, fols. 2r-2v. 
se verifica en el presente caso por la cituacion de Marani y la mía, porque ni su hijo ni su familia en nada pueden desmerecer con el referido casamiento, como es notorio y constante, ni entre nosotros puede mirarse el asunto con la delicadeza que en otras personas. Y así, este negocio no está comprehendido en la letra de dicha Real Pragmática. ${ }^{82}$

El documento al que se refieren es la Pragmática Sanción sobre matrimonios desiguales promulgada por Carlos III en 1776 en España, cuya validez se extendió a América en 1778, acompañada por una Cédula de adecuaciones al contexto de las colonias. En virtud de dicho documento, de hecho, el expediente que nos ocupa se encuentra en el ramo Civil del Archivo General de la Nación, ya que una de las disposiciones dictadas fue precisamente el cambio de atribución, del fuero religioso al fuero civil, de las causa de disenso, $\mathrm{u}$ oposiciones a los matrimonios.

La intención primaria de la ley fue impedir los matrimonios socialmente desiguales, instituyendo la obligación del consentimiento de los padres para los menores de 25 ańos. Parece ser que las adaptaciones a América sí incluyeron el aspecto racial: ${ }^{83}$ la inconformidad de Marani tenía, entonces, sustento jurídico en disposiciones además muy recientes. Disposiciones que hablan del desasosiego de las elites y la preocupación del poder ante el (imparable e inevitable) fenómeno social de la movilidad social y el mestizaje racial. Un desasosiego que, a su vez, permea otras capas de la sociedad, otros individuos que tratan de apropiárselo para su propia legitimación simbólica. Girolamo Marani, el director de la compañía de bailarines del Coliseo, tenía por lo visto un alto concepto de su prestigio social, propio y de su familia. La admisión de pobreza en nada parece empañarlo.

La contienda genera cientos de folios repartidos en desperdigados expedientes, ${ }^{84}$ reflejo del ahínco con que fue peleada, amén de la

${ }^{82}$ AGN, Civil, vol. 843, exp. 1, fol. 5 v.

${ }^{83}$ A reservas de consultar el texto original de la Pragmática, los comentarios que he leído concuerdan sobre este aspecto. Véase por ejemplo Luis Felipe Pellicer, "Entre el honor y la pasión. Familia y matrimonio en Venezuela, 1778-1821", en Dimensiones del diálogo americano contemporáneo sobre la familia en la época colonial, ed. Francisco Chacón Jiménez y Ana Vera Estrada, 128-130 (Murcia: Universidad de Murcia, 2009).

${ }^{84}$ AGN, Civil, vol. 843, exps. 1, 2 y 3; Indiferente Virreinal, Sección Matrimonios, 
inversión de tiempo y gastos. La batalla en la arena simbólica, sin embargo, importa aquí más que la batalla meramente legal. Girolamo Marani y Felipa Mercado protagonizan dicha batalla, más que sus hijos, cuya presencia es casi siempre indirecta: Juan Marani desaparece después de la petición que detona el pleito legal, Bárbara Álvarez no es ni siquiera llamada a declarar. La batalla simbólica es entre los padres que, a través de los hijos, pelean su propio lugar y posición en las sutiles jerarquías estamentarias, amén del consiguiente trato y reconocimento que creen les corresponde. Alrededor del historial familiar de Bárbara se desencadena una enredadada lucha burocrática en que se esgrimen partidas de bautismo, declaraciones de supuestas autoridades competentes, acusaciones más o menos explícitas de corrupción de las autoridades susodichas, presentación de testigos y contratestigos, declaraciones animadas de Girolamo y Felipa. La una argumenta que el linaje suyo y de su esposo es espańol, aunque humilde y expósito; el otro rebate que Felipa Mercado es hija de una "india tocha" ${ }^{85}$ y su esposo también es de mestiza descendencia. Los ires y venires de esta rebatinga son largos y enmarańados. Girolamo Marani, por ejemplo, consigue una serie de testimonios de vecinos de Maravatío, a los que Felipa Mercado rebate, apelando a un total de otros doce testigos presentados a favor de su condición decente de española. Además, la mujer no se limita a defenderse y justificarse, sino que a su vez pone en cuestión la calidad de Girolamo Marani y los suyos. "La Ytalia" que para Girolamo significa indudable, intachable limpieza de sangre, se vuelve, en el discurso de Felipa, un territorio desconocido, fuera de los dominios del católico rey de España, poblado por castas y religiones más amenazadoras por ignotas. La mujer llega a insinuar que, por lo que se sabe, los Marani pudieran ser hasta mahometanos:

caja 2,500, exp. 29; Indiferente Virreinal, caja 4,173, exp. 6; Inquisición, vol. 725, exp. 1; Inquisición, vol. 1,378, exp. 2.

85 "India tocha, que así se llama en aquel pueblo la que aquí embuelta, que es la que no usa de naguas" (AGN, Civil, vol. 843, exp. 1, fol. 14v [2]), es decir, que lleva el tradicional refajo ([2] señala que la foliación marcada en el expediente se interrumpe y vuelve a empezar). 
A más de esto, yo era la que debía pedir justificara su calidad, así por ser su hijo el pretendiente de mi hija, como por ser estrangero, nacido en tierras estrańas, y sin ser basallo de nuestro católico monarca y soberano. [...] De Marani no sabemos otra cosa más que haverse aparecido en este reyno de vailarín, sin saber de dónde es, ni quiénes son sus padres, ni su tierra, ni su religión..$^{86}$ [...] Ni yo ni ninguno de México sabe quién es Marani ni si es o no christiano, o de Ytalia, o de Turquía, y solo se sabe porque él lo dice y nada más. Pero suponiendo, como lo supongo y lo creo, que sea christiano, y que sea nacido de la tierra donde dice, consiento en el matrimonio de su hijo con mi hija. ${ }^{87}$

Felipa Mercado, en su contraataque, se ciñe a señas de identidad y pertenencia de las que su antagonista carece: la condición de súbdito español, el derecho documentado de piso en el lugar donde trabaja y vive. Esas señas de identidad la hacen sentir con derecho a revertir los argumentos de Marani y ponerse en la posición magnánima de quien se digna emparentar con una familia de orígenes dudosos (probablemente, su favor también se explica con que, habiendo promesa de matrimonio de por medio, Juan y Bárbara ya habían consumido sus amores, y a la madre de la chica por lo mismo le urgía que se casaran). A Girolamo Marani, por su parte, quien desde sus comienzos en Europa ha conocido las durezas y las estrecheces del oficio, del otro lado del mar le da por querer que se le reconozca, formal y oficialmente, una superioridad racial y social con respecto a sus compañeros de trabajo, nativos de la Nueva España. Su condición de italiano lo hace limpio de sangre, afirma; pero eso no es todo. Girolamo, coup de théâtre, a lo largo de toda la disputa declara que él y su familia, además, son nobles. Felipa Mercado tiene sus dudas al respecto y las expresa con cierta sorna e ironía: "Conque si Marani no ha justificado su alta nobleza, lo devemos juzgar por el estado en que lo vemos, de bailarín pantomino $[s i c]$ de este público Coliseo. Y, por consiguiente, ni él ni su familia pierden ni se infaman con el casamiento de mi hija, aun en el negado caso de que fuéramos de mala calidad" ${ }^{88} \mathrm{El}$

\footnotetext{
${ }^{86}$ AGN, Civil, vol. 843, exp. 1, fols. 6r-6v.

${ }^{87}$ AGN, Civil, vol. 843, exp. 1, fol. 16v [2].

${ }^{88}$ AGN, Civil, vol. 843, exp. 1, fol. 18r [2].
} 
abogado de Girolamo se lanza en una larga y prolija justificación de por qué el ejercicio de bailarines no sería incompatible con el estado de nobleza. Nótese como se reivindica la modernidad del presente, en el sentido de que los tiempos de "la andante cavallería", en que los nobles despreciaban cualquier oficio, han quedado atrás. Hay hasta cierta insinuación de que se trata de un atraso de mentalidad muy espańol, con respecto al resto de Europa:

Las ocupaciones y exercicios, aunque sean teatrales y escénicos, nunca envilecen a los que los exercen [...] Así se discurría en los tiempos de la andante cavallería, y solo en España, porque en el resto de la Europa, y especialmente en la Ytalia, los personages más ilustres han exercido oficios mecánicos, y los nobles no se han desdeñado de las ocupaciones teatrales, escénicas. ${ }^{89}$

Los argumentos del abogado son bastante débiles: de hecho, por ejemplo, una de las polémicas que en el siglo xvi causó en Italia la emergencia, afirmación y éxito de la Commedia dell'Arte, donde por "arte" justamente se entiende "oficio", estribó en el desprecio, manifestado por parte de las aristocráticas academias de aficionados al teatro, hacia el hecho de que los commedianti cobraban por sus representaciones. Los nobles eruditos, que escribían y representaban piezas teatrales por desinteresado deleite, consideraban a los profesionales del escenario como unos viles mercenarios que prostituían el noble arte dramático. ${ }^{90} \mathrm{Al}$ margen de estas consideraciones, de todos modos, es bastante sospechosa e improbable esta repentina nobleza de Girolamo y Teresa, nunca mencionada antes en ningún documento, ni en su partida de matrimonio, ni en las partidas de bautismo de sus hijos, por ejemplo. A todas luces, nunca la pudieron demostrar. Me inclino a pensar que sea una invención de Girolamo, engañosamente confiado en que de su condición -italiano y director artístico en el teatro principal de México- a la de noble no hubiera más que un paso insignificante, por lo cual su prentensión de nobleza resultaría creíble. Tuvo que desengañarse. Amén de todas las veces

${ }^{89}$ AGN, Civil, vol. 843, exp. 1, fols. 42v y 46v.

${ }^{90}$ Véase, por ejemplo, el clásico estudio de Roberto Tessari, Commedia dell'Arte: la Maschera e l'Ombra (Milán: Mursia, 1981). 
en su vida en que, muy poco noblemente, tuvo que pelear por su salario, al final tuvo también que resignarse a la boda de su hijo Juan con Bárbara. Evidentemente, las autoridades competentes dieron la razón a Felipa Mercado y deliberaron que todos los involucrados eran de la misma clase, casta o calaña, según quiera verse, y que no existía, o no merecía la pena reconocerse, desigualdad de estado alguna que estorbase el happy end. En ninguno de los expedientes que en el Archivo General de la Nación resguardan los papeles relativos al caso aparece la resolución de éste; sin embargo, el ramo Genealogías del mismo archivo nos cuenta que la pareja se casó el 23 de marzo de 1793 en la parroquia del Sagrario Metropolitano, la catedral. La partida de matrimonio asienta que Bárbara era espańola, y, para esto, Juan también, habiendo nacido en Ayamonte. ${ }^{91}$ No deja de ser una ironía de la historia que los dos hayan visto reconocida su igualdad y, por ende, su derecho a casarse, bajo la etiqueta de una nacionalidad que para ambos era, finalmente, bastante ficticia: Bárbara nunca pisó España, y Juan nació de padres italianos y con ellos creció. Su nacimiento en Espańa fue azaroso: de haber nacido tan sólo unas horas antes en el recorrido de sus padres, del otro lado del río Guadiana, hubiera sido portugués. Juan y Bárbara tuvieron tres hijos: María Blasa Vicenta de la Santísima Trinidad, nacida el 4 de febrero de 1793 (más de un mes antes de la boda de sus padres); Juana María de Guadalupe Josefa Cayetana Paula, nacida el 17 de junio de 1795; y Marco Cristóval José Luis, nacido el 7 de octubre de $1796 .{ }^{92}$

\section{TelóN}

¿Habrá asistido Girolamo a la boda de su hijo Juan, o habrá preferido no tener que soportar la sorna triunfante en la cara de Felipa, consuegra muy a su pesar? No lo sabemos. En cualquiera de los casos, podemos imaginar su frustración, probablemente análoga a la que le ha de haber dado al no poder cobrar sus deudas íntegras a

${ }^{91}$ AGN, Genealogías, C-ZE P-DR R-286, fol. 88v.

${ }^{92}$ AGN, Genealogías, C-ZE P-OAH R-50, fol. 53v; C-ZE P-OAH R-51, fols. 93v. y $156 r$. 
Vizente Gerardi y al Hospital de Naturales, o a la ocasionada cuando tuvo que doblar la cabeza y sujetarse a las órdenes del virrey Revillagigedo, poco dispuesto a darle el lugar que él creía merecer. Este tipo de frustraciones, causadas por el divorcio entre la percepción de su propio valor y el lugar que de facto le reconocía el mundo en que vivía, parecen haber sido una constante en la vida del andariego artista italiano. En la encarnizada y extenuante batalla legal que libró para hacer valer su oposición a las nupcias de su hijos parece haberse vertido la única reacción posible que le fuera dada, desde su posición de autoridad paterna, hacia un entorno que se empecinaba en colocarlo en la miseria cuando él se sentía con derecho a la nobiltà: él, el apreciado artista italiano llegado a la Nueva España por invitación personal de un virrey; él, el maestro a quien estuvo encomendada la profesionalización y calidad del Coliseo; él, que vestía magníficos vestuarios en Venecia y en América poseía, a su decir, un inventario de valiosos enseres de su oficio. Algo de ese altanero orgullo se le pegó a sus hijos Juan y Juana, cuyo carácter desesperaba al administrador Joseph del Rincón. Todos ellos, finalmente, terminaron acatando las decepciones de su estado y siguieron su vida en la nueva tierra que, entre contradicciones, dificultades y efímeros triunfos, terminó siendo su patria más duradera.

\section{BIBLIOTECAS Y ARCHIVOS CONSULTADOS}

ACJ Archivo de la Compañía de Jesús, Cartuja de Granada

AGI Archivo General de Indias, Sevilla

AGMAB Archivo General de la Marina "Álvaro de Bazán", Viso del Marqués (Ciudad Real)

AGN Archivo General de la Nación, México.

AHCN Archivo Histórico del Colegio Notarial, Zaragoza

AHINAH Archivo Histórico del Instituto Nacional de Antropología e Historia, México.

AHMC Archivo Histórico Municipal, Cádiz

AHMZ Archivo Histórico Municipal, Zaragoza

AHPC Archivo Histórico Provincial, Cádiz

AHPZ Archivo Histórico Provincial, Zaragoza 
ANRC Archivo Nacional de la República de Cuba, La Habana

ANTT Arquivo Nacional Torre do Tombo, Lisboa

APCSC Archivo Parroquial de la Catedral de la Santa Cruz, Cádiz

APNSA Archivo Parroquial de Nuestra Señora de las Angustias, Ayamonte

APSL Archivio Parrocchiale di San Luca, Venezia

ASPV Archivio Storico del Patriarcato, Venezia

ASM Archivio di Stato, Milano

ASV Archivio di Stato, Venezia

BCG Biblioteca Casa Goldoni, Venezia

BCSC Biblioteca del Conservatorio "Santa Cecilia”, Roma

BCGBM Biblioteca del Conservatorio "Giovan Battista

Martini", Bologna

BMC Biblioteca del Museo Correr, Venezia

BMD Biblioteca del Museo de la Danza, La Habana

BNB Biblioteca Nazionale Braidense, Milano

BNC Biblioteca Nacional de Cuba, La Habana

BNE Biblioteca Nacional de España, Madrid

BN-FR Biblioteca Nacional de México, Fondo Reservado, México.

BNM Biblioteca Nazionale Marciana, Venezia

BNP Biblioteca Nacional de Portugal, Lisboa

Bibliografía

Amore in tarantola. Dramma giocoso per musica. Venezia: Modesto Fenzo (impresor), Teatro San Moisè, 1750.

Arco, Ricardo del. Zaragoza histórica: evocaciones y noticias. Madrid: Tipografía de la viuda de Justo Martínez, 1928.

Dallal, Alberto. La danza en México. Segunda parte. México: UNAM, 1989.

Diago Hernando, Máximo y Miguel Ángel Ladero Quesada. "Caminos y ciudades en España de la Edad Media al siglo XvıII", En la España medieval (33) (2010): 347-382.

Doménech Rico, Fernando. Los Trufaldines y el Teatro de los Caños 
del Peral. La commedia dell'arte en la España de Felipe V. Madrid: Fundamentos, 2007.

EgIDO, Aurora. Bosquejo para una historia del teatro en Aragón hasta finales del siglo XVIII. Zaragoza: Institución Fernando el Católico, 1987.

Fatás Cabeza, Guillermo. De Zaragoza. Zaragoza: Institución Fernando el Católico, 1990.

Gazeta de México, núm. 39, martes 7 de junio de 1785.

Guía de forasteros, núms. I-7.

LASSO DE LA VEGA, Ángel. Autores aragoneses del teatro antiguo español. Zaragoza: La Cadiera, 1951.

Locatelli, Stefano. Edizioni teatrali nella Milano del Settecento. Per un dizionario bio-bibliografico dei librai e degli stampatori milanesi e annali tipografici dei testi drammatici pubblicati a Milano nel xviii secolo. Milán: ISU Università Cattolica, 2007.

Mañón, Manuel. Historia del Teatro Principal de México. Ed. facsimilar. México: Conaculta, INBA (Cultura), 2009 [1932].

María y Campos, Armando de. Andanzas y picardías de Eusebio Vela. México: Compañía de Ediciones Populares, 1944.

. Entre cómicos de ayer. Apostillas con ilustraciones sobre el teatro en América. México: Arriba el Telón, 1949.

. Guía de representaciones teatrales en la Nueva España. México: B. Costa-Amic, s/f.

Olavarría y Ferrari, Enrique de. Reseña histórica del teatro en México. Vol. I. México: Porrúa, 2002.

Olmedo Checa, Manuel y Francisco Cabrera Pablos. Bernardo de Gálvez y su tiempo. http://www.asociacionbernardogalvez.es/ art/bernardo-de-galvez-y-su-tiempo.php (Fecha de consulta: junio 2014).

Pellicer, Luis Felipe. "Entre el honor y la pasión. Familia y matrimonio en Venezuela, 1778-1821". En Dimensiones del diálogo americano contemporáneo sobre la familia en la época colonial, ed. Francisco Chacón Jiménez y Ana Vera Estrada, 127-154. Murcia: Universidad de Murcia, 2009.

Prospecto del drama histórico nuevo en tres actos, titulado: Llegar a tiempo: que a beneficio del maestro de escoleta D. Antonio Solo y Zaldi- 
var, ha de representarse en el teatro de esta ciudad de la Puebla de los Angeles, la noche del domingo 25 de enero de 1807. Puebla: s/e.

Ramos Smith, Maya. La danza en México durante la época colonial. México: Conaculta, Alianza Editorial Mexicana, 1990.

- Los artistas de la feria y de la calle: espectáculos marginales en la Nueva España (1519-1822). México: Conaculta, INBA, CITRU, 2010.

. El actor en el siglo XVIII entre el Coliseo Nuevo y el Teatro Principal. México: Escenología, Conaculta, INBA, 2013.

SaAvedra, Francisco de. Los decenios (Autobiografia de un sevillano de la Ilustración), ed. Francisco Morales Padrón. Sevilla: Excmo. Ayuntamiento, 1995.

SASPORTES, José. "Il Settecento portoghese rivisitato all'italiana". En La danza italiana in Europa nel Settecento, ed. José Sasportes, 137-174. Roma: Bulzoni, 2011.

Tessari, Roberto. Commedia dell'Arte: la Maschera e l'Ombra. Milán: Mursia, 1981.

Verti, Roberto. Un almanacco drammatico. L'indice de' teatrali spettacoli 1764-1823. 2 Vols. Pesaro: Fondazione Rossini, 1996.

VIVERos, Germán. Manifestaciones teatrales en Nueva España. MéxiCO: UNAM, 2005.

. Teatro dieciochesco de Nueva España. México: unAm, 2010. . Escenario novohispano. México: Espasa, Academia Mexicana de la Lengua, 2013.

WIEL, Taddeo. Teatri musicali veneziani del Settecento. Catalogo delle opere in musica rappresentate nel secolo XVIII a Venezia. Venezia: Arnaldo Forni, 1897 [Las citas de esta publicación se referencian a través del número de catálogo en ella asignado al libretto]. 